\title{
DOLOČANJE MEJE MED MESTOM IN PODEŽELJEM S POMOČJO SPOZNAVNIH ZEMLJEVIDOV (NA PRIMERU OBČINE IZOLA)
}

Špela Guštin, univ. dipl. geogr.

Rakovčeva ulica 2, SI-6330 Piran

e-mail: spela.gustin@gmail.com

Izvirni znanstveni članek

COBISS 1.01

DOI: 10.4312/dela.41.7.129-144

\section{Izvleček}

Razmejevanje mesta in podeželja je na videz nesmiselno, a je potrebno pri pripravi prostorskih dokumentov. S spoznavnimi zemljevidi smo anketirali 25 prebivalcev občine. 68 \% vprašanih je mejo med mestom in podeželjem zarisalo po obvoznici, kar se ujema z načrtovano širitvijo poselitve mesta Izola. Na podlagi teh ugotovitev in ugotovljenih neskladij v prostoru predlagamo možno razmejitev med mestom in podeželjem. Razmejitev je lahko v pomoč pri načrtovanju prihodnjega prostorskega razvoja občine.

Ključne besede: podeželje, mesto, občina Izola, spoznavni zemljevid

\section{USING COGNITIVE MAPS FOR DEFINING THE BORDER BETWEEN RURAL AND URBAN AREAS (THE CASE OF IZOLA MUNICIPALITY)}

\begin{abstract}
Dividing rural and urban areas seems pointless, yet it is necessary in spatial planning. We used cognitive mapping to survey 25 inhabitants of Izola municipality. $68 \%$ of surveyed people perceive the bypass as the border between rural and urban areas. This opinion matches the municipality's long-term spatial plan. Based on these findings and on recognized land use conflicts, we propose a possible border between rural and urban areas. It can be used in planning the future spatial development of municipality.
\end{abstract}

Key words: rural areas, urban areas, Izola municipality, cognitive maps 


\section{UVOD}

Primerjava več različnih opredelitev in tipologij podeželja (Perpar, Kovačič, 2002; Ravbar, 2003; Prikaz stanja prostora ..., 2011; Pavlin in sod., 2004) samo še podkrepi dejstvo, da imamo še zmeraj težave z opredelitvijo podeželja. Ali podeželje v neki občini obstaja ali ne, je odvisno od uporabljene prostorske enote (občina, krajevna skupnost, naselje) in od uporabljenih kazalcev za določanje 'podeželskosti'. Razlike v raznovrstnih opredelitvah in tipologijah podeželja so velike. Tematika je precej kompleksna, kar potrjujejo tudi na Kmetijski svetovalni službi v Kopru (Sotlar, 2013).

Med mestom in podeželjem ni jasne meje, ampak območje postopnega prehoda, kjer se prepletajo podeželske in mestne funkcije (ruralno-urbani kontinuum; Geografski terminološki slovar, 2005). Razmejevanje takega prehodnega območja s črto se sliši nesmiselno, a se ga včasih zahteva, npr. pri določanju enot urejanja prostora, da je mejo možno prikazati v zemljiškem katastru (Zakon o prostorskem načrtovanju, 2007).

Namen tega članka je opredeliti mejo med mestom in podeželjem v občini Izola. Ker se tipologije in opredelitve podeželja tako zelo razlikujejo med sabo, smo uporabili drugačen pristop: o tem smo vprašali prebivalce. Domnevamo, da ima občina Izola po mnenju njenih prebivalcev podeželje ter da jih bo veliko za mejo med mestom in podeželjem izbralo obvoznico. Obvoznica je po Lynchu (1974) zelo učinkovita meja, saj je neprekinjena in težko prehodna v prečni smeri.

\section{I. Podeželje v občini Izola}

Podeželje v občini Izola je bilo posredno opredeljeno že nekajkrat, npr. pri izdelavi različnih tipologij podeželja Slovenije ali opredelitvah mest, vendar skoraj vsakič drugače (slika 1).

Prostorski planerji (Prikaz stanja prostora ..., 2011) podeželje opredelijo tako, da določijo ureditveno območje naselja Izola (slika 1a). Če si to, na papirju začrtano, mejo ogledamo v naravi, je ponekod precej nesmiselna (slika 2). Meja med ureditvenim območjem naselja (mestom) in podeželjem (vsem ostalim, kar ni mesto) lahko poteka tudi po sredini asfaltirane ceste. Z osnutkom občinskega prostorskega načrta občine je širjenje poselitve dolgoročno predvideno do hitre ceste (obvoznice; Občinski prostorski ..., 2013, str. 34). Del občine izven ureditvenega območja naselja Izola se ureja s Prostorskimi ureditvenimi pogoji za podeželje (Odlok o prostorskih ..., 1989).

Statistični urad (slika 1b) je za potrebe statističnega izkazovanja izdelal lastno opredelitev mestnega naselja (Pavlin in sod., 2004). Kot mestno naselje so na podlagi števila prebivalcev (nad 3000) opredelili Izolo, kot obmestno naselje pa Jagodje (sklenjena pozidava z Izolo, zaposlitvena navezanost na Izolo ter nizek delež kmetij). Ostalih sedem naselij je torej podeželskih.

Tipologijo podeželskih območij (slika 1c) sta izdelala tudi Perpar in Kovačič (2002). Za osnovno prostorsko enoto sta uporabila krajevno skupnost. Krajevne skupnosti, ki niso bile mestne, sta opredelila kot podeželske. V občini Izola je pet krajevnih skupnosti, le ena, največja (KS Korte), je podeželska. 
Podeželje občine Izola je opredeljeno tudi v Razvojnem programu podeželja občin Koper, Izola in Piran 2007-2013 (2006, str. 77) in obsega »... teritorij občine, ki se razprostira južno od mesta Izola. Meja območja je obalna cesta proti Kopru na vzhodni strani, južni rob industrijskih objektov ob Industrijski cesti in obdelovalne površine južno od Južne obvoznice, področje južno in zahodno od naselja Jagodje oz. od objektov Belvedere. V podeželsko območje tako spadajo vzhodni del primestnega naselja Polje, naselje Dobrave, razpršeni stavbni objekti nad obalno cesto proti Kopru in Južno obvoznico ter vsa vaška naselja v občini: Korte z zaselki ...; Šared z zaselki ...; Cetore, Medljan, Malija, Baredi in Nožed.« Ta opredelitev je le opis meje ureditvenega območja naselja Izola (slika 1a).

Ravbar (2003) je pri členitvi slovenskega podeželja uporabil raven naselja (slika 1č). Po njegovi tipologiji so v občini Izola mesto Izola, tri urbanizirana, prehodna in stabilna podeželska naselja (Malija, Nožed, Baredi), ostala (Jagodje, Šared, Cetore,

Slika 1: Opredelitve podeželja v občini Izola po različnih tipologijah oziroma tipizacijah: a) Prikaz stanja prostora ..., 2011; b) Pavlin in sod., 2004; c) Perpar, Kovačič, 2002; č) Ravbar, 2003 Figure 1: Different typologies of rural areas in Izola municipality: a) Prikaz stanja prostora ..., 2011; b) Pavlin in sod., 2004; c) Perpar, Kovačič, 2002; č) Ravbar, 2003
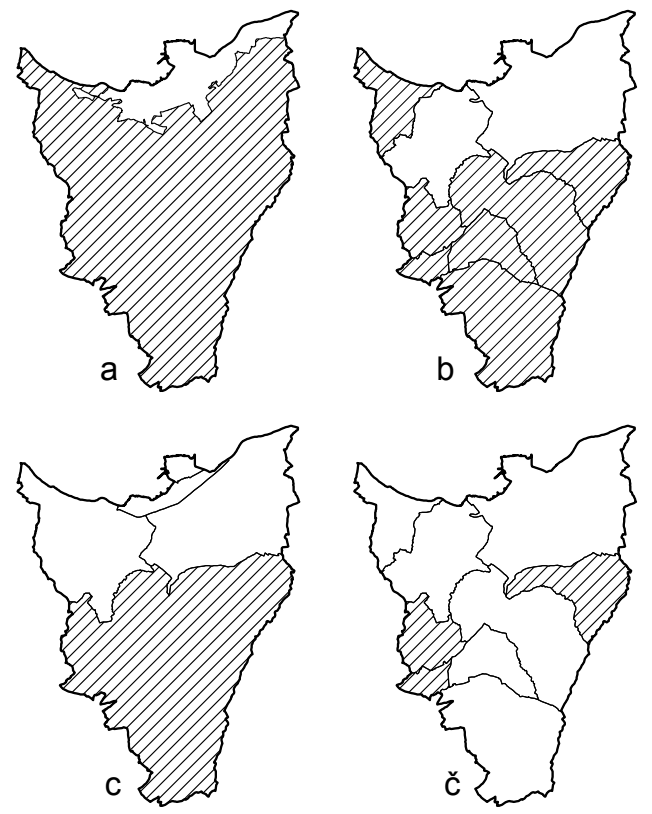

DP podeželje

mesto in obmestje

urban and suburban areas

Vir podatkov:

- meja naselij, krajevnih skupnosti, občine (GURS)

- ureditveno območje naselja Izola (Občina Izola)

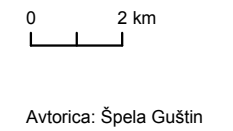


Dobrava) so močno urbanizirana obmestja. Na njegovem zemljevidu je kot mestno označeno tudi naselje Korte, ki pa se po tipologiji središčnih naselij uvršča med središčna podeželska naselja prve stopnje (Benkovič Krašovec, 2006), zato domnevamo, da je na zemljevidu prišlo do napake.

Po zemljevidu Model litoralizacije ob slovenski obali (Černe, Kušar, 2012, str. 217) ima občina Izola urbano aglomeracijo (Izolo) in suburbanizirano območje (vse ostalo). Podeželja ni v občini Izola niti po tipologiji, izdelani na ravni občine, ki jo uporablja Eurostat (Kartografski prikaz ..., 2013), po kateri je celotna občina del prehodnega območja, niti po tipologiji, ki jo je naredila Lužnikova (2010) v diplomski nalogi (celotna občina je pretežno urbana), niti po Krevsovi tipologiji (1999) - celotno občino sestavljajo mestne in obmestne krajevne skupnosti.

Za opredeljevanje podeželja se v novejšem času uporablja še drugačen pristop, ki podeželje opredeljuje kot družbeni konstrukt (Woods, 2005). Poudarek ni več na kvantitativnih kazalcih, ampak na predstavah ljudi (prebivalcev), ki nekemu območju pripisujejo podeželske lastnosti. Predstave ljudi pa so zelo različne in zato tudi isto območje opredeljujejo zelo različno, odvisno od starosti, izkušenj in različnih interesov (Turk Niskač, Klaus, Starec, 2010).

Slika 2: Meja med podeželjem (levo) in mestom (desno) je v prostorskih dokumentih občine Izola začrtana po sredini Južne ceste. Levih pet prog zebre je 'podeželskih', preostale so 'mestne' (foto: $\check{S}$. Guštin)

Figure 2: The middle of the Southern road separates rural (left) and urban areas (right) in the municipal spatial planning documents. Left five stripes of the zebra crossing are 'rural', the remaining stripes are 'urban' (photo: $\check{S}$. Guštin)

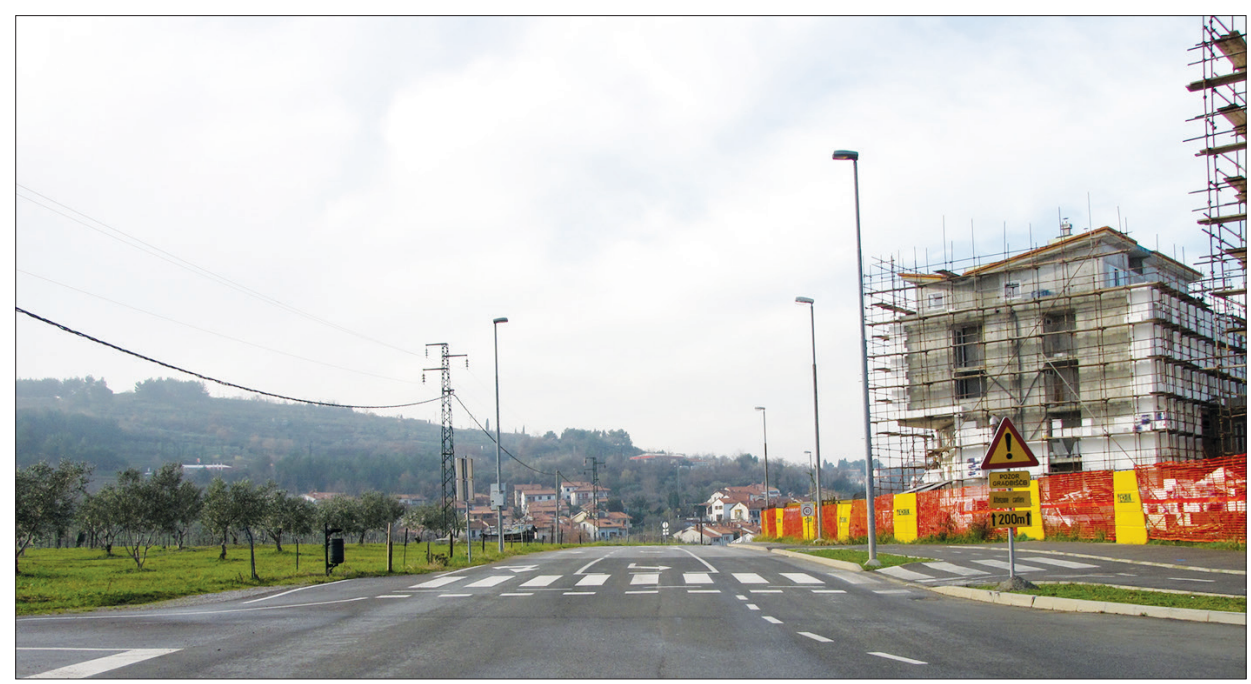




\section{METODA}

\section{I.Spoznavni zemljevidi}

Okolje nam nudi več obvestil, kot jih zmoremo uporabiti. Da se v njem znajdemo, iz te množice informacij uporabimo le tiste, ki so za nas pomembne. V glavi si ustvarimo miselni okvir, sliko okolja, s katerim si pomagamo v vsakdanjem življenju (Kaplan, Kaplan, Ryan, 1998). To je naš 'spoznavni zemljevid', ki kaže našo uporabo prostora in omogoča predvidevanje njegove bodoče uporabe (Polič, 2002).

Človeške glave so slabi mediji za prenašanje informacij. Zemljevida vanj ne moremo enostavno namestiti, kot bi naložili program v računalnik, ampak ta nastaja počasi in je odvisen od posameznikovega okolja, izkušenj, izobrazbe (Kaplan, Kaplan, Ryan, 1998). Prav zaradi tega vsak drugače 'zemljevidi' (Kos, 2002, str. 102). Vsak spoznavni zemljevid je nepopoln (nekatera območja v njem ne obstajajo) in poenostavljen, je pa za posameznika uporaben. Na njem so kraji in območja, ki so zanj pomembni. Kraji, ki jih ne obiskuje, na tem zemljevidu pogosto manjkajo, na njem pa se lahko znajdejo tudi kraji ali poti, ki ne obstajajo, a si želi, da bi (Polič, 2002).

Spoznavni zemljevidi so »skonstruiran prostor želja in domišljije« (Kos, 2002, str. 102), zaradi česar prihaja do razlik v dojemanju istega prostora med različnimi skupinami ljudi, še posebno pa med uporabniki prostora in njegovimi načrtovalci (Polič, 2002; Gifford in sod., 2002; Kaplan, Kaplan, Ryan, 1998), vendar se slednji teh razlik ne zavedajo (Kaplan, Kaplan, Ryan, 1998).

V okolju smo najbolj pozorni na in si najbolj zapomnimo tiste elemente, ki so edinstveni in čitljivi, in tiste, ki so za nas uporabni (Polič, 2002). V mestih je take edinstvene prvine okolja opredelil Lynch (1974): poti, robovi/meje, četrti, vozlišča in znamenja. Meje oziroma robovi ločujejo dvoje območij. Najmočnejše se zdijo tiste meje, ki so zelo opazne, neprekinjene in neprehodne v prečni smeri.

Spoznavni zemljevid imamo v glavi, zato je drugim neviden. Eden izmed načinov njegovega sporočanja je risanje (Polič, 2002), zato je tak način pridobivanja informacij od ljudi neke vrste grafično anketiranje (Golobič, 2006). Če ljudem damo v roke svinčnik in papir, lahko s pomočjo spoznavnih zemljevidov zvemo npr.:

- kako ljudje dojemajo mesto (Lynch, 1974);

- da obstaja razlika med spoznavnimi zemljevidi ljudi, ki poznajo kraj le z zemljevida in tistimi, ki tam živijo (Lloyd, 1989);

- kaj ljudje smatrajo za sosesko (Lee, 1968; cv: Polič, 2002);

- kateri deli zvezne države Pensilvanija (ZDA) so podeželski (Jacob, Luloff, 1995);

- kako si Slovenci predstavljajo slovenske pokrajine (Klemenčič, 2002);

- katere dele Radenskega polja bi zavarovali (Polič, Mencin, Bartol, Marušič, 1991; cv: Marušič, 2002);

- kam bi prebivalci občine Komenda umestili določene dejavnosti za potrebe izdelave prostorskega plana občine (Golobič, 2006);

- kakšno je poznavanje vodovarstvenih pasov na Ljubljanskem polju in Iškem vršaju (Smrekar, 2006);

- kje v Sloveniji je meja Mediterana (Staut, Kovačič, Ogrin, 2007). 
$\mathrm{Z}$ uporabo metode spoznavnih zemljevidov lahko pridobimo veliko informacij (Marušič, 2002), vzorci, ki nam jih ljudje sporočajo $\mathrm{z}$ risanjem takih zemljevidov, pa so pomemben podatek prostorskemu načrtovalcu. Iz njih lahko razbere, zakaj pri sporazumevanju z različnimi uporabniki prostora prihaja do nesporazumov (Kos, 2002). Če teh vzorcev ne pozna, je njegov načrt lahko neuporaben (Polič, 2002). Z uporabo te metode pridobimo rezultate, ki so odvisni od izkušenj, izobrazbe in okolja anketirancev ter so zato vsakič drugačni. Niso natančni, ne moremo jih prikazati v zemljiškem katastru in niso le ena črta, ampak množica le-teh, v kateri ni samo enega pravilnega odgovora. Rezultate je potrebno ustrezno interpretirati, pri čemer je v veliko pomoč računalniška analiza (Marušič, 2002).

\subsection{Anketa}

Anketa je bila sestavljena iz barvnega izseka iz preglednega zemljevida občin Koper, Izola in Piran v merilu 1:45.000 z vrisano mejo občine in mejami krajevnih skupnosti ter iz osnovnih demografskih podatkov anketiranca (spol, starost, kraj bivanja, izobrazba, poklic). Anketiranci, ki so na vprašanje Ali v občini Izola imamo podeželje? odgovorili z 'da',

Slika 3: a) Model rasterizacije digitaliziranih poligonov; b) model reklasifikacije rastrskih slojev in c) model izvoza rastrskih slojev v ASCII datoteko z orodjem Model Builder v programu ArcMap Figure 3: ArcMap Model Builder: a) model of rasterization of digitized polygons; b) model of reclassification of raster layers and c) model of export of raster layers to ASCII file

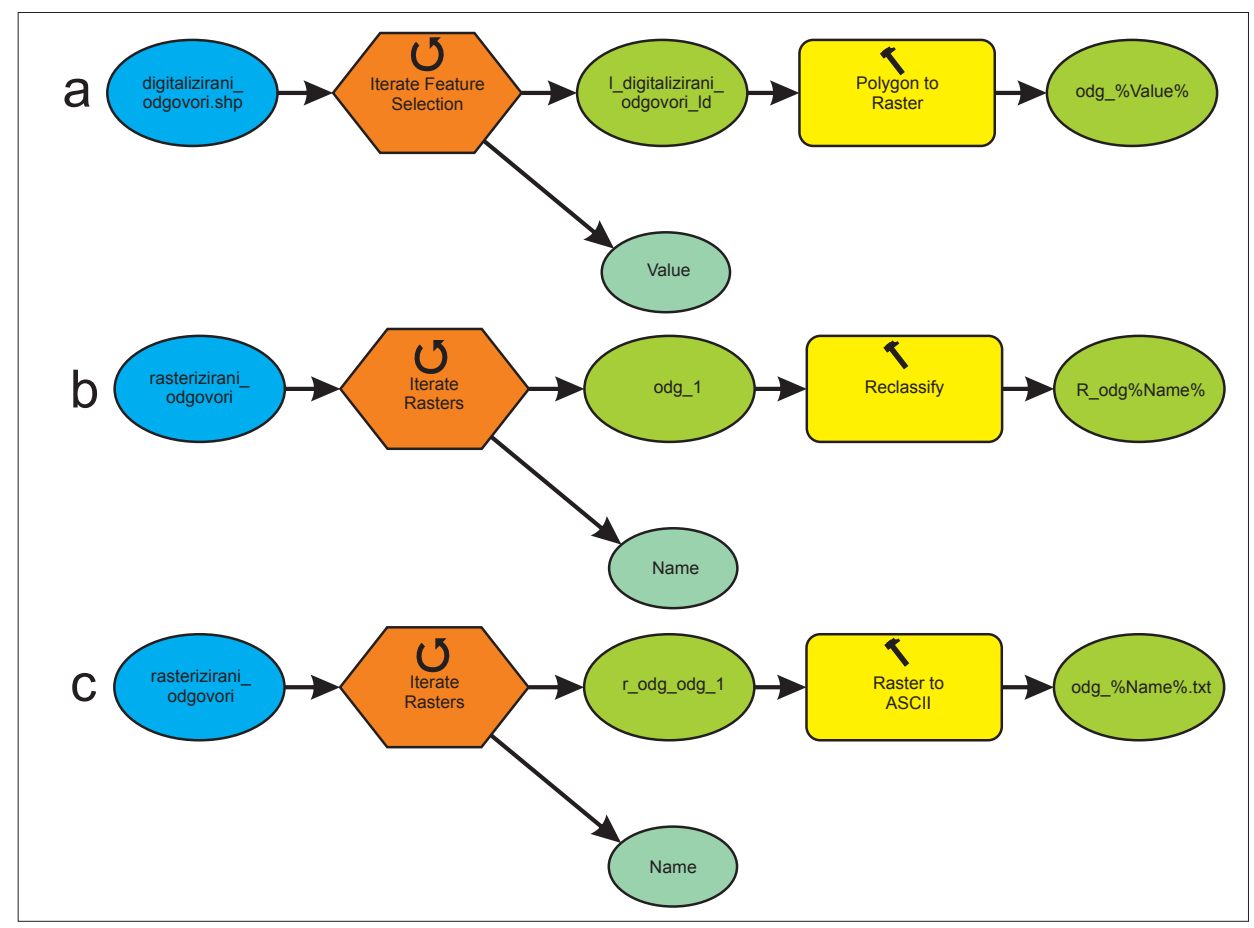


so nato dobili nalogo, naj na zemljevid narišejo, kje po njihovem mnenju poteka meja med mestom in podeželjem. 'Grafično' anketiranih je bilo 25 ljudi iz vseh devetih naselij občine. Vsi so menili, da občina Izola ima podeželje, zato je vseh 25 tudi risalo mejo. Za pomoč pri georeferenciranju je imel zemljevid v vsakem vogalu križec, ki je omogočal hitrejše vpenjanje skeniranega zemljevida v programu ArcMap in kasnejše digitaliziranje odgovorov.

\subsection{Analiza prekrivanja dobljenih odgovorov in problem velikega šte- vila poligonov}

Vse odgovore, ki so jih anketiranci zarisali na zemljevid, smo digitalizirali kot poligone v programu ArcMap 10.1. Vsak odgovor (poligon) je dobil svojo ID številko, v pripadajočo vrstico v atributni tabeli pa smo vpisali demografske podatke, ki jih je navedel anketiranec. $\mathrm{Na}$ tak način lahko odgovore s pomočjo ukaza Select by Attributes med seboj primerjamo po različnih kriterijih in vidimo, kako podeželje vidijo različne skupine ljudi.

Da bi ugotovili, kateri deli občine so bili največkrat izbrani kot podeželski in kje prihaja do razhajanj, smo poligone med sabo sešteli v programu Idrisi Selva. Za seštevanje poligonov morajo biti ti posebej pripravljeni.

Ker je poligonov veliko, smo si pomagali z orodjem Model Builder, ki je del programa ArcMap. Tako ni treba rasterizirati, reklasificirati in izvažati vsakega poligona posebej, ampak sestavimo model (slika 3) s pomočjo ukaza Iterate (ponavljaj), ki zaporedje danih ukazov ponavlja, dokler ne zmanjka poligonov oziroma rastrskih slojev (A quick tour ..., 2013). Da lahko izhodne datoteke ločimo med sabo, jih model poimenuje z enoličnim identifikatorjem, ki ga določimo sami. Identifikator pripnemo na konec imena izhodne datoteke tako, da ga zapišemo med dvema znakoma \% (npr. \%Value\%). Model rasterizacije je prikazan na sliki 3a. Rastrske sloje reklasificiramo tako, da ima poligon identifikator 1 , vse ostalo pa 0 (slika 3 b), nato pa pretvorimo v ASCII datoteke (slika 3c), ki jih lahko uvozimo v Idrisi. Pred uvažanjem teh datotek v Idrisi moramo zamenjati decimalne vejice s pikami. Za uvoz uporabimo ukaze Import - Software specific formats - ESRI formats - ARCRASTER - ASCII to raster. V Idrisiju sloje seštejemo s pomočjo ukaza Raster Calculator. Rezultat je zemljevid odgovorov, ki nam pokaže, katera območja so po mnenju anketirancev podeželska, katera mestna in kje je odločanje o tem težavno (slika 5).

\section{REZULTATI IN RAZPRAVA}

\section{I. Meja med mestom in podeželjem po obvoznici}

$\mathrm{Z}$ uporabo metode spoznavnih zemljevidov smo ugotovili, da je obvoznica po mnenju občanov občine Izola zelo izrazita meja, ki jo je narisal vsaj eden od vprašanih iz vsakega naselja občine Izola. Skupaj je mejo po obvoznici narisalo 68 \% vseh vprašanih (17 anketirancev).

Anketirance, ki so risali mejo po obvoznici, lahko razdelimo v dve skupini glede na to, ali so na zahodu (na odcepu za Izolo) nadaljevali z risanjem po cesti proti Strunjanu ali so zavili proti severu in omejili mesto glede na gostoto pozidave. $Z$ nadaljevanjem po 
cesti so vključili v mestno območje tudi krajinski park Strunjan, z zavojem proti severu pa so krajinski park izločili in ga priključili podeželju. Na vzhodu takega razhajanja ni bilo, čeprav je tam tudi cestni odcep proti bolnišnici. Izmed tistih, ki so mejo narisali po obvoznici, sta bolnišnico v severovzhodnem delu občine vštela v mesto le dva anketiranca. Po registru prostorskih enot je bolnišnica del naselja Izola, čeprav bi iz njenega naslova (Polje 40) lahko sklepali drugače.

Na izločitev območja bolnišnice iz območja mesta sta verjetno vplivala tudi relief in raba tal. Bolnišnica je na nadmorski višini okoli $120 \mathrm{~m}$ in se po tem razlikuje od obalne ravnice, kjer je mesto Izola. Območje ni gosto poseljeno, prevladujejo nasadi vinske trte. Prostorski plan občine Izola uvršča območje bolnišnice v ureditveno območje naselja Izola (slika 1a). Glede na prevladujoče mnenje, da je območje podeželsko, čeprav ga prostorski dokumenti opredeljujejo kot mestno, bi tu lahko pričakovali konflikte v rabi tal. To nakazuje že sprejetje začasnih ukrepov za zavarovanje prostora (Odlok o začasnih ukrepih za varovanje ..., 2013, str. 18) z namenom preprečitve »... utemeljene nevarnosti, da bo sicer izvedba prostorske ureditve onemogočena ali močno otežena oziroma, da se bodo bistveno zvišali stroški njene izvedbe, ali da bodo za njeno izvedbo potrebni znatno povečani posegi $\mathrm{v}$ pravice in pravne koristi lastnikov nepremičnin in drugih prizadetih subjektov, ob tem pa se v območju omogoči možnost izvajanja posameznih del.« (slika 6). Na tem območju so prepovedane gradnje, zasaditev trajnih nasadov in parcelacije (Odlok o začasnih ukrepih za varovanje ..., 2013).

Južno od območja bolnišnice poteka gradnja hitre ceste, ki bo s predorom Markovec povezala Koper in Izolo (Uredba o državnem ..., 2004; slika 6). Ceste imajo velik vpliv na dojemanje meje. Eden od anketirancev je povedal, da se mu zdi, da Šared zdaj ni mesto, ko pa bo zgrajena slemenska cesta Jagodje-Šared, bo postal del mesta. Tudi zato predvidevamo, da bo novozgrajena hitra cesta postala nova meja med mestom in podeželjem. Meja se bo verjetno premaknila južneje in proč od obale ter bo podobna meji, ki so jo nekateri risali na zahodu.

\subsection{Meja med mestom in podeželjem po amfiteatru}

Polkrožni del občine Izola, ki se dviguje od morja do vrha gričevnatih pobočij na jugu, je zaradi oblike dobil ime amfiteater (Gabrijelčič, 1988). Anketiranci, ki niso narisali meje po obvoznici, so jo potegnili po slemenu ali po njegovem severnem pobočju in s tem zarisali mejo območja, za katerega se v občinskih prostorskih dokumentih uporablja izraz 'amfiteater'. Anketiranci tukaj ne soglašajo tako prepričljivo, kot pri meji po obvoznici. Vseeno pa lahko najdemo med zarisanimi črtami nekatere skupne poteze. Na vzhodu so mejo največkrat potegnili po ali tik pod slemenom, na zahodni strani pa po slemenski cesti, kjer je v pripravi gradnja povezovalne ceste Jagodje-Š́ared. Obratno kot pri meji po obvoznici anketiranci bolj soglašajo glede meje na vzhodu, na zahodu pa prihaja do večjih razlik (zračna razdalja med posameznimi zarisanimi črtami na zahodu je tudi več kot dva kilometra).

Območje amfiteatra je močno zavarovano: na državni ravni kot izjemna krajina (Hudoklin in sod., 2005), na lokalni ravni pa kot kulturna krajina (Register nepremične 
kulturne dediščine, 2013). Na območju kulturne krajine se »... varujejo vse naravne in antropogene značilnosti pred posegi, ki bi negativno vplivali na nadaljnjo degradacijo ambientalno-krajinske podobe naravnega amfiteatra. Novogradnje so prepovedane, možni so omejeni nujni posegi za kmetijsko rabo s predhodnim soglasjem pristojne službe za varstvo naravne in kulturne dediščine, v kolikor ne degradirajo kulturne podobe amfiteatra. Območje na slemenu je nezazidljivo. (Križan, 1995, str. 27). Pobočje je prepredeno s hudourniškimi grapami, v vodoravni smeri pa s tradicionalnimi obdelovalnimi terasami (Križan, 1995).

Območje, ki se dviga od obvoznice proti slemenu na jugu, je po prostorskem planu občine Izola izven ureditvenega območja naselja Izola (slika 1a). Podobno kot pri območju bolnišnice je tudi tu kar nekaj anketirancev mnenja, da je območje mestno, čeprav ga prostorski dokumenti opredeljujejo kot podeželsko. Ureja se z Odlokom o prostorskih ureditvenih pogojih za podeželje (1989). Zato ni nepričakovano, da v strokovnih podlagah varstva naravne in kulturne dediščine ugotavljajo, da se tu pojavljajo prostorsko nesprejemljivi objekti in infrastrukturne povezave (Križan, 1995). Zaradi neskladij v dojemanju okolja lahko tudi na pobočjih amfiteatra pričakujemo konflikte v rabi tal.

Slika 4: Meje med mestom in podeželjem v občini Izola, kot so jih narisali anketiranci $(N=25)$ Figure 4: Borders between urban and rural areas in the municipality of Izola, as drawn by all those surveyed $(N=25)$

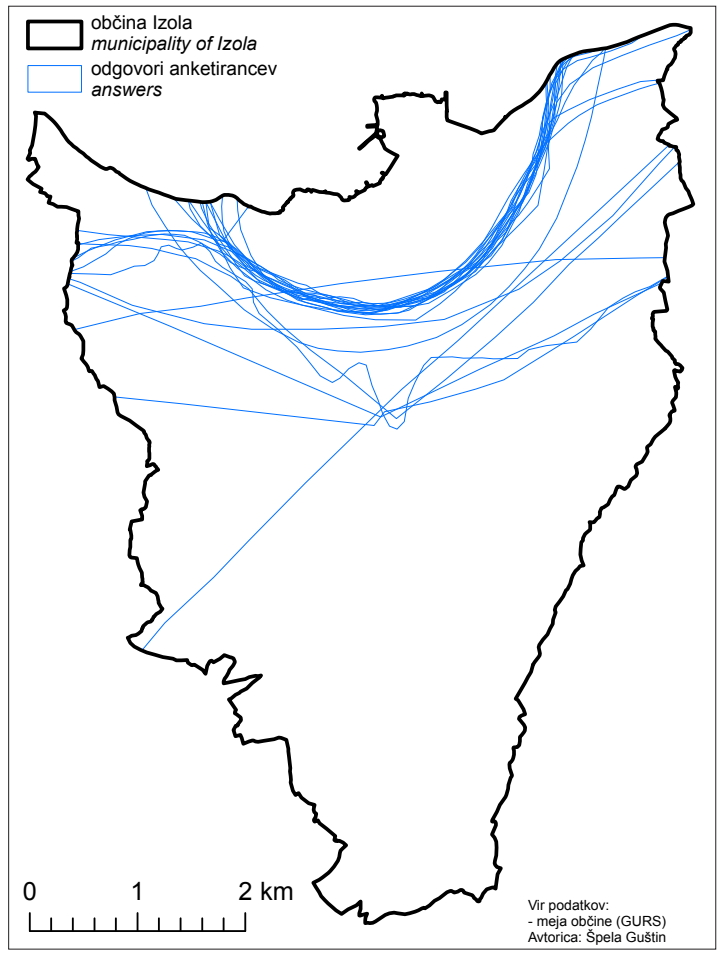


Slika 5: Seštevek vseh odgovorov z dodanimi mejami naselij

Figure 5: Sum of all answers with added settlement borders

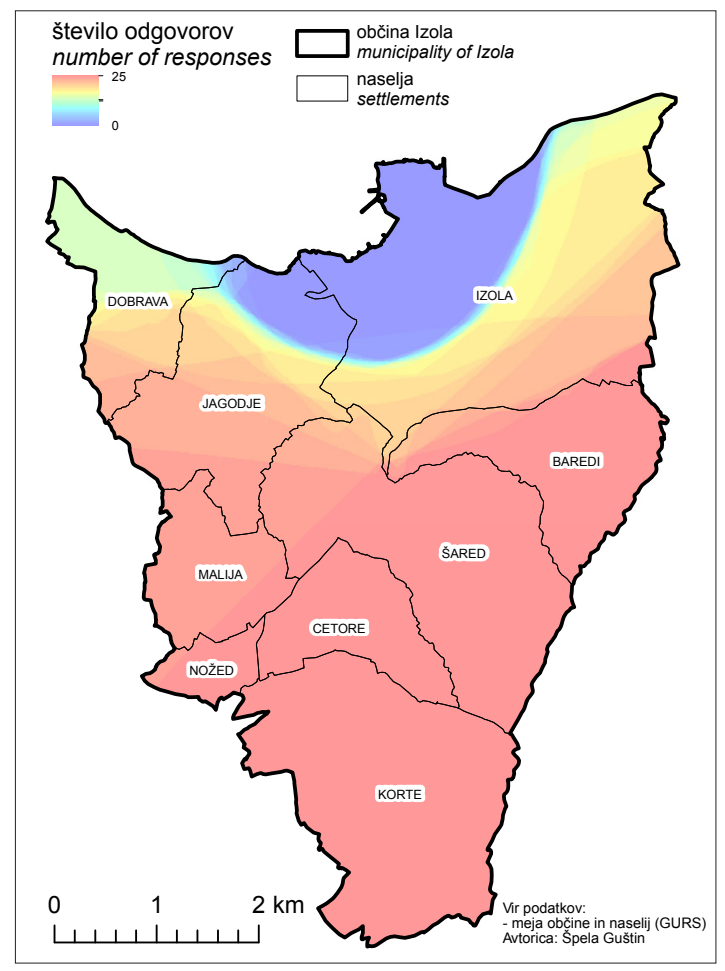

\subsection{Kje je meja med mestom in podeželjem?}

Marušič (2002) se je spraševal, kje naj planer potegne mejo, ko dobi v roke množico črt, ki so jih ljudje zarisali na zemljevid. Tam, kjer je črto narisalo največ ljudi?

Če bi upoštevali najpogosteje začrtano mejo, bi v občini Izola lahko rekli, da je meja med mestom in podeželjem obvoznica. To se ujema z občinskimi prostorskimi dokumenti in opredelitvijo podeželja, kot jo razumejo prostorski načrtovalci: »Podeželje je območje zunaj urbanih območij.« (Strategija prostorskega razvoja Slovenije, 2004, str. 10).

S potegom črte na zemljevidu so ljudje občino razdelili na dve območji. Seštevek vseh območij nam pokaže, koliko anketirancev soglaša, da je območje severno/južno od narisane črte mestno/podeželsko. Južno od najjužneje zarisanih črt je območje, za katerega se vsi anketiranci strinjajo, da je podeželsko. Na sliki 6 je to območje označeno s črko B. Na enak način dobimo območje, za katerega vsi mislijo, da ni podeželsko, oziroma, da je mestno. Na sliki 6 je označeno s črko A. Glede na njihove predstave domnevamo, da je meja med mestom in podeželjem tako nekje med območjema A in B. Takšne vmesne prostore med podeželjem in mestom so Turk Niskač in sod. (2010, str. 10) poimenovali 
Slika 6: Predlagana meja upošteva odgovore anketirancev in vključuje območja, kjer so zaznani konflikti v rabi tal

Figure 6: Proposed border (dashed line) takes into account the answers of surveyed people and areas with recognized land use conflicts

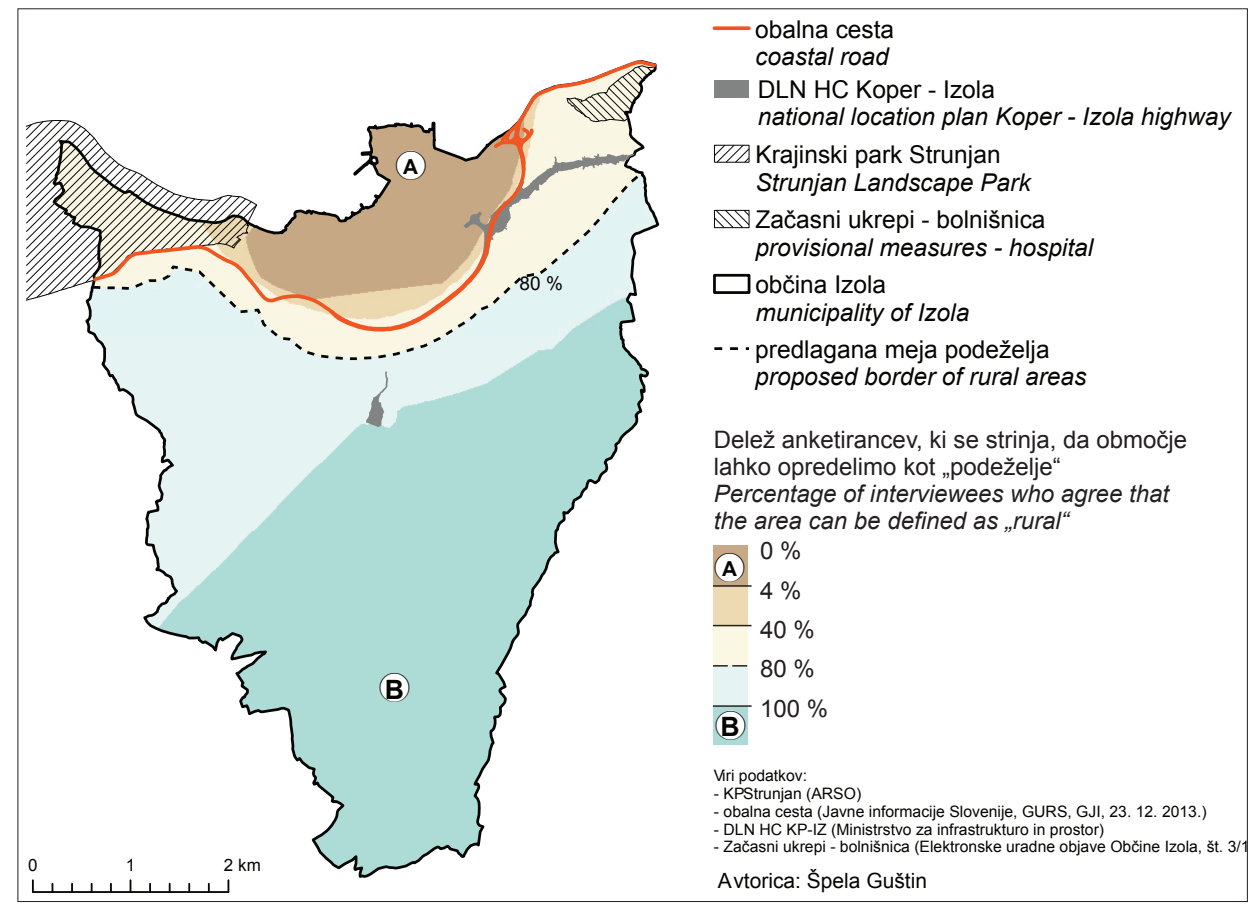

'dvakratno obrobje': hkrati so obrobje podeželja in mesta. Prav zaradi neopredeljenosti so zanimivi za najrazličnejše dejavnosti in uporabnike, v slovenski prostorski praksi pa se v njih pojavljajo vprašljivi posegi v prostor, povezani z močnimi interesi in šibko prostorsko zakonodajo (Simoneti, 2000).

Če sklepamo samo na podlagi odgovorov anketirancev, se pomisleki o ločitvi med mestom in podeželjem pojavijo šele tik pred obvoznico. Po prečkanju obvoznice pa hitro pridemo do črte, kjer kar 80 \% vprašanih soglaša z razmejitvijo (slika 6).

Če za mejo izberemo črto, kjer dosežemo 80 \% soglasje vprašanih, se precej približamo meji, ki sta jo določila Perpar in Kovačič (2002; slika 1c). Podeželsko območje v tem primeru vključuje šest naselij v celoti (Korte, Cetore, Malija, Nožed, Šared, Baredi) ter dele naselij Jagodje, Dobrava in Izola. Obsega 72,3 \% površja občine. Kot 'mestno' so poleg mesta Izola opredeljeni tudi območje bolnišnice, Krajinski park Strunjan in vznožje pobočja amfiteatra. Podeželsko je tudi območje južno od bolnišnice, kjer je v izgradnji nova hitra cesta, ki naj bi bila dokončana v letu 2014 (Avtoceste ..., 2014) in bo verjetno postala nova meja med mestom in podeželjem. 


\section{SKLEP}

Razmejitev mesta in podeželja je težavna, kar lahko opazimo iz številnih poskusov opredelitve mesta in podeželja. Pri soočenju z zapleteno nalogo je človeku, ki je postavljen pred nalogo razmejitve dveh območij, ločnica v prostoru (na primer obvoznica) v veliko pomoč. Je zelo enostavna in logična izbira, če o razmejevanju mesta in podeželja ni nikoli razmišljal. Težko jo je prečkati, hrup vozil pa ustvarja še dodaten 'zvočni zid'. Obnašanje ljudi se nam pogosto zdi popolnoma nerazumljivo, a je v resnici preprosto - za nerazumevanje je krivo zapleteno okolje, v katerem ljudje živijo (Gould, White, 2002). Obvoznica je primer razumljivega in čitljivega okolja, v katerem se ljudje znajdejo. Pomaga pri razumevanju prostora, je jasna meja, četudi mogoče ne najprimernejša.

Poskusi razmejitve mesta in podeželja dajejo zelo različne rezultate. Po mnenju prebivalcev meja ni ena sama. Lahko bi rekli, da je meja bolj ali manj široka črta, sestavljena iz množice črt, ki se prepletajo. Vse so pravilne, vsakemu pa se zdi najbolj pravilna tista, ki jo zariše sam. To je tudi razlog za neskladja med dojemanjem prostora ljudi in uradnimi prostorskimi dokumenti, zato smo poskušali predlagati drugačno mejo. Spoznavni zemljevidi nam jasno pokažejo, kje lahko zaradi napačnega razumevanja okolja in razhajanja mnenj med načrtovalci prostora in njihovimi uporabniki pričakujemo nasprotujoče si želje po spremembah rabe tal.

Metoda se je izkazala za uporabno, saj je potrdila tudi dejstva o konfliktih v prostoru, ki nastajajo zaradi različnega dojemanja istega okolja. Na rezultate bi se verjetno dalo vplivati z manipulacijo zemljevida, na katerega so anketiranci risali odgovore. Če bi obalno cesto na njem namenoma zarisali malo drugače, bi tisti, ki so risali mejo po cesti, verjetno zaradi tega mejo potegnili drugače.

Spoznavni zemljevidi niso statični, a so vseeno zelo odporni na spremembe (Polič, 2002). Z izgradnjo nove hitre ceste Koper-Izola in prestavitvijo obalne ceste v predor Markovec, bo v prostoru nastala nova meja. Takrat bi anketo lahko ponovili. Spoznavni zemljevidi bi se z novo mejo verjetno spremenili, a ta sprememba ne bi bila takojšnja. Prostorski načrtovalec bi pa moral biti pozoren nanjo, saj napoveduje tudi druge spremembe: pritiske po pozidavi in špekulacije $\mathrm{z}$ zemljišči.

\section{Viri in literatura}

Avtoceste in hitre ceste v gradnji. DARS. URL: http://www.dars.si/Dokumenti/O_avtocestah/AC_in_HC_v_gradnji_354.aspx (Citirano 23. 10. 2014).

A quick tour of using iterators for iteration - (Looping). ArcGIS Help. 2013. URL: http:// help.arcgis.com/en/arcgisdesktop/10.0/help/index.html\#//002w0000001w000000 (Citirano 20. 8. 2013).

Benkovič Krašovec, M., 2006. Centralna naselja na podeželju v Sloveniji. Geografski obzornik, 53, 3, str. 10-18.

Černe, A., Kušar, S., 2012. Regionalni razvoj Obalno-kraške statistične regije in ocena stopnje litoralizacije. V: Ogrin, D. (ur.). Geografija stika Slovenske Istre in Tržaškega zaliva (Zbirka GeograFF, 12). Ljubljana, Znanstvena založba Filozofske fakultete, str. 193-218. 
Gabrijelčič, P., 1988. Posebna merila in pogoji za ruralno območje planskih celot 7, 8, 9, 11, 12 in 13 za podeželje občine Izola. Ljubljana, VTOZD Arhitektura, Fakulteta za arhitekturo, Univerza Edvarda Kardelja v Ljubljani, 20 str.

Geografski terminološki slovar. 2005. Kladnik, D., Lovrenčak, F., Orožen Adamič, M. (ur.). Ljubljana, Založba ZRC, 451 str.

Gifford, R., Hine, D. W., Muller-Clemm, W., Shaw, K. T., 2002. Why architects and laypersons judge buildings differently: Cognitive properties and physical bases. Journal of architectural and planning research, 19, 2, str. 131-148. URL: http://web.archive.org/ web/20100911102240/http:/web.uvic.ca/psyc/gifford/pdf/Why architects and laypersons judge buildings differently Cognitive and physical bases (2002).pdf (Citirano 7. 2. 2013).

Golobič, M., 2006. Kartiranje normativnega znanja: spoznavni zemljevidi in GIS. V: Perko, D., Nared, J., Čeh, M., Hladnik, D., Krevs, M., Podobnikar, T., Šumrada, R. (ur.). Geografski informacijski sistemi v Sloveniji 2005-2006. Ljubljana, Založba ZRC, str. 159-168.

Gould, P., White, R., 2002. Mental maps. 2. izdaja. London, Routledge, 172 str.

Hudoklin, J., Selak, I., Simič, S., Ogrin, D., 2005. Ohranjanje prepoznavnosti slovenskih krajin: podrobnejša pravila za urejanje prostora. Ciljni raziskovalni projekt: Konkurenčnost Slovenije 2001-2006: tretje poročilo. Novo mesto, Acer, 72 str. URL: http:// www.arhiv.mop.gov.si/fileadmin/mop.gov.si/pageuploads/podrocja/prostor/pdf/crp/ crp.pdf (Citirano 9. 2. 2013).

Jacob, S., Luloff, A. E., 1995. Exploring the meaning of rural through cognitive maps. Rural sociology, 60, 2, str. 260-273. DOI: 10.1111/j.1549-0831.1995.tb00572.x

Kaplan, R., Kaplan, S., Ryan, R., 1998. With people in mind: design and management of everyday nature. Covelo (CA), Island Press, 239 str.

Kartografski prikaz občin po konceptu Stopnja urbanizacije (Eurostat). 2013. URL: http://www.stat.si/doc/vsebina/podezelje/občine po stopnji urbanizacije.JPG (Citirano 17. 2. 2013).

Klemenčič, M. M., 2002. Miselna slika pokrajin. V: Polič, M., Repovš, G. (ur.). Spoznavni zemljevid Slovenije. Ljubljana, Znanstveni inštitut Filozofske fakultete, str. $161-180$.

Kos, D., 2002. Množenje prostorskih podob. V: Polič, M., Repovš, G. (ur.). Spoznavni zemljevid Slovenije. Ljubljana, Znanstveni inštitut Filozofske fakultete, str. 97-117.

Krevs, M., 1999. Glavne razlike v življenjski ravni med slovenskimi mestnimi, obmestnimi in podeželskimi območji. Dela, 14, str. 151-162. URL: http://revije.ff.uni-lj.si/ Dela/article/view/1291/1095 (Citirano 20. 2. 2013).

Križan, B., 1995. Spremembe in dopolnitve planskih aktov občine Izola 1986-19902000. Posebne strokovne podlage varovanja naravne in kulturne dediščine; tekstualni del. Piran, MZVNKD Piran, 67 str.

Lee, T., 1968. Urban neighbourhood as a socio-spatial schema. Human relations, 21, 3, str. 241-267. DOI: 10.1177/001872676802100303

Lloyd, R., 1989. Cognitive maps: encoding and decoding information. Annals of the Association of American Geographers, 79, 1, str. 101-124. DOI: 10.1111/j.14678306.1989.tb00253.x 
Lužnik, J., 2010. Določitev tipologije podeželskih območij. Diplomsko delo. Ljubljana, Fakulteta za gradbeništvo in geodezijo, 71 str. URL: http://drugg.fgg.uni-lj.si/221 (Citirano 17. 2. 2013).

Lynch, K., 1974. Slika jednog grada. Beograd, Građevinska knjiga, 234 str.

Marušič, I., 2002. Planiranje. V: Polič, M., Repovš, G. (ur.). Spoznavni zemljevid Slovenije. Ljubljana, Znanstveni inštitut Filozofske fakultete, str. 119-160.

Občinski prostorski načrt občine Izola - osnutek. 2013. 49 str. URL: http://www.izola. info/doc/Odlok_OPN_osnutek.pdf (Citirano 11.2. 2014).

Odlok o prostorskih ureditvenih pogojih za »podeželje občine Izola«. 1989. Uradne objave občine Izola, 35, str. 241-244.

Odlok o začasnih ukrepih za varovanje območja ob svetilniku, Cankarjev drevored-sever, bolnišnice in Šared. 2013. Elektronske uradne objave Občine Izola, 3, str. 18-21. URL: http://izola.si/wp-content/uploads/2014/02/URADNE_OBJAVE_3-2013-1.pdf (Citirano 28. 8. 2013).

Pavlin, B., Milenković, A., Klasinc, S., Grm, B., 2004. Mestna naselja v Republiki Sloveniji. 2003. Ljubljana, Statistični urad RS, 140 str. URL: http://www.stat.si/doc/pub/ mestna_naselja_slo_03.pdf(Citirano 8.2. 2013).

Perpar, A., Kovačič, M., 2002. Tipologija in razvojne značilnosti podeželskih območij v Sloveniji. Dela, 17, str. 85-99. URL: http://revije.ff.uni-lj.si/Dela/article/ view/1335/1139 (Citirano 11. 11. 2014).

Polič, M., Mencin, M., Bartol, B., Marušič, J., 1991. Stališča prebivalcev občine Grosuplje do nekaterih vidikov njenega razvoja. Grosuplje, Občina Grosuplje, 47 str.

Polič, M., 2002. Doumevanje okolja. V: Polič, M., Repov̌̌, G. (ur.). Spoznavni zemljevid Slovenije. Ljubljana, Znanstveni inštitut Filozofske fakultete, str. 15-55.

Prikaz stanja prostora občine Izola - grafični del, osnutek. 2011. Domžale, Locus d.o.o., 16 str.

Ravbar, M., 2003. Značilnosti urbanizacije. V: Fridl, J., Kladnik, D., Orožen Adamič, M., Perko, D. (ur.). Geografski atlas Slovenije: država v prostoru in času. Ljubljana, DZS, str. 310-313.

Razvojni program podeželja za območje občin Koper, Izola in Piran. 2006. Koper, Regionalni razvojni center Koper, 158 str. URL: http://www.rrc-kp.si/images/stories/dokumenti/pdf/RAZVOJNI-PROGRAM-PODEZELJA.pdf (Citirano 18. 5. 2013).

Register nepremične kulturne dediščine. Ministrstvo za kulturo. 2013. URL: http://giskd2s.situla.org/rkd/Zacetek.asp (Citirano 9. 2. 2013).

Simoneti, M., 2000. Možnosti in priložnosti vmesnih prostorov: prostorsko planiranje temelj za realizacijo prostorskih potencialov. V: Geršak Podbreznik, A., Novak, M. (ur.). Vmesni prostor regije - vmesni prostor mesta. 16. Sedlarjevo srečanje, zbornik referatov. Rogaška Slatina, Društvo urbanistov in prostorskih planerjev Slovenije, str. 24-30.

Smrekar, A., 2006. From drawing cognitive maps to knowing the protection zones for drinking water resources. Acta geographica Slovenica, 46, 1, str. 7-31. DOI: 10.3986/AGS46101

Sotlar, M., 2013. Meja med mestom in podeželjem v občini Izola (osebni vir, 29. 1. 2013). Koper. 
Strategija prostorskega razvoja Slovenije. 2004. Ljubljana, Ministrstvo za okolje, prostor in energijo, Direktorat za prostor, Urad za prostorski razvoj, $75 \mathrm{str}$.

Staut, M., Kovačič, G., Ogrin, D., 2007. The spatial cognition of Mediterranean in Slovenia: (in)consistency between perception and physical definitions. Acta geographica Slovenica, 47, 1, str. 105-131. DOI: 10.3986/AGS47105

Turk Niskač, B., Klaus, S., Starec, S., 2010. Urbano življenje ob kmetijah ali ruralno življenje ob stolpnicah? Dilema jasne ločnice med urbanim in ruralnim. Urbani izziv, 21, 1, str. 32-41. URL: http://urbani-izziv.uirs.si/Portals/uizziv/papers/urbani-izziv-2010-21-01-003.pdf (Citirano 20. 10. 2014).

Uredba o državnem lokacijskem načrtu za hitro cesto na odseku Koper - Izola. 2004. Uradni list RS, 112, str. 13397-13416. URL: http://www.pisrs.si/Pis.web/pregledPredpisa?id=URED3512 (Citirano 11. 11. 2014).

Woods, M., 2005. Rural geography: processes, responses and experiences in rural restructuring. London, Sage, 336 str.

Zakon o prostorskem načrtovanju (ZPNačrt). 2007. Uradni list RS, 33, str. 4585-4602. URL: http://www.pisrs.si/Pis.web/pregledPredpisa?id=ZAKO4675 (Citirano 12. 12. 2013).

\section{USING COGNITIVE MAPS FOR DEFINING THE BORDER BETWEEN RURAL AND URBAN AREAS (THE CASE OF IZOLA MUNICIPALITY)}

\section{Summary}

Rural areas in Izola municipality have been defined indirectly and in various ways, when making typologies of Slovenian rural or urban areas. Their comparison shows that the results of such typologies depend on spatial unit used for data collection. There is no obvious border between both areas; it is not a line but a gradient. Dividing it with a line seems pointless and at the same time necessary in spatial planning. Spatial planners define rural areas as areas outside urban areas. In Izola municipality these areas are regulated by an official document. The border between urban and rural areas, as defined in spatial planning documents, can seem unusual when one locates it outdoors.

The quantity of data with which people operate every day can be overwhelming. To simplify it we make a mental picture of the world we live in. This is our mental map that shows our use of the environment and at the same time makes it possible to plan the future use of the same environment. Mental maps develop over time, they are simplified, inaccurate and they depend on the environment in which we live. A mental map of a person can be obtained by graphic enquiry - we ask the person to draw the map for us. Patterns in these drawings can be used by spatial planners for understanding miscommunications between various stakeholders and for prevention of possible conflicts among them. The method provides results that can vary greatly and are different each time we use it. Therefore, it does not give us a definite answer and defining a meaningful one requires careful interpretation.

We asked 25 inhabitants of Izola municipality to draw the border between rural and urban areas on a pre-made map. The results were digitized and overlaid with GIS. The 
map shows the bypass as a strong border in people's minds, because it was chosen as such by $68 \%$ of respondents. Respondents that did not draw the border on the bypass drew it on the ridge or on the slopes south of the bypass that are mostly shaped by visible and unique natural or human-made landscape characteristics. By doing this, they defined the area known in municipal spatial planning documents as an amphitheatre.

If we took into account only the frequency of responses, we could say the bypass is the border between rural and urban areas in Izola municipality. However, if we look at the problem from different viewpoints and consider all the responses, the areas with recognized land use conflicts, and the new highway that should be finished in 2014, this border moves away from the bypass and towards the south. $80 \%$ of respondents agree with the border drawn in this way and the rural area, defined by it, covers $72.3 \%$ of the municipality. Inhabitants' mental map of the border between urban and rural areas will probably change with the completion of the Koper-Izola highway south of the hospital. Spatial planners should be aware of these changes because they lead to further pressures for land use change and speculation.

(Translated by the author) 